\title{
Angles
}

New Perspectives on the Anglophone World

$10 \mid 2020$

Creating the Enemy

\section{Mad, Bad and Dangerous to Know? Hoodies in Contemporary British Horror Cinema}

\section{Anne-Lise Marin-Lamellet}

\section{(2) OpenEdition}

1 Journals

\section{Electronic version}

URL: http://journals.openedition.org/angles/453

DOI: 10.4000/angles.453

ISSN: 2274-2042

\section{Publisher}

Société des Anglicistes de l'Enseignement Supérieur

\section{Electronic reference}

Anne-Lise Marin-Lamellet, « Mad, Bad and Dangerous to Know? Hoodies in Contemporary British Horror Cinema », Angles [Online], $10 \mid$ 2020, Online since 01 April 2020, connection on 10 December 2020. URL : http://journals.openedition.org/angles/453 ; DOI : https://doi.org/10.4000/angles.453

This text was automatically generated on 10 December 2020.

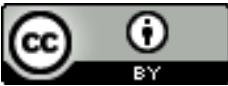

Angles est mise à disposition selon les termes de la Licence Creative Commons Attribution 4.0 International. 


\title{
Mad, Bad and Dangerous to Know? Hoodies in Contemporary British Horror Cinema
}

\author{
Anne-Lise Marin-Lamellet
}

When a photo of a group of perfectly ordinary lads, just standing around wearing hooded tops, has become visual shorthand for urban menace, or even the breakdown of society, it's clear that teenage boys have a serious image problem.

(Fiona Bawden 2009)

The late 2000s and early 2010s saw the rise of a new subgenre in British horror cinema now often referred to as hoodie horror. This cycle of films, usually said to have opened with Eden Lake in 2008 (Walker 2016: 90), which is thought to have both revived and renewed the great British Gothic tradition (Simpson 2012: 13), emerged in the wake of a series of articles about that garment turned into an allegory of crime. More generally, it belongs to the very large group of films that have endeavoured to feature young people and adolescent idiosyncrasies since the post-war era, probably owing to the concurrent emergence of the concept of the teenager (Brighton Rock, Cosh Boy, Violent Playground, The Boys), and that have, to this day, tended to show youth as a social problem (Teds, Mods, Rockers, punks, skinheads, ravers, hoodies, chavs, etc.). Horror-wise, hoodie horror is a broad church generically speaking as it draws on several influences such as the thriller and the supernatural, relying besides on typical horror subgenres such as survival, slasher, home invasion, redneck/backwoods, and found footage. This cycle of films thus stands at the crossroads of two major British cinematic traditions, i.e. social realism and horror. Despite the variations, the basic plot uniting these films is that of a gang of hooded youths preying on adults ("mugging" that can escalate into manslaughter or murder). Beyond the age-old generation gap, class proves a fundamental aspect in the subgenre. However, the approach seems to be based on a moral rather than a strictly sociological premise. The victims of hoodies can be middleclass but also working-class, in other words people deemed respectable pitted against 
what is perceived to be an increasingly rougher underclass, using a dichotomy that is highly reminiscent of the old Victorian distinction to establish social hierarchy. The confrontation is always between "us" and "them". Although the number of films that can be considered the hard core of the subgenre is relatively small, many other contemporary films featuring hoodies include a scene or build an atmosphere that draws on their horrific nature, as if all these films captured the zeitgeist of millennial Britain. Government and media campaigns against antisocial behaviour or Broken Britain undoubtedly helped revive the stereotype of a rebellious and dangerous youth, a great cinematic trope (Brooke 2014), fostering a moral panic which culminated with the summer riots of 2011. For a while, both films and tabloids regularly pictured faceless young offenders and the figure of the hoodie became iconic on and off screen. The enemy image of the hoodie was, therefore, not a cinematic creation but these films certainly contributed to further anchor the negative assumptions associated with that new bogeyman, which earned the subgenre a bad reputation as if it was playing its part in the general obfuscation of class consciousness and struggle. But there might be more than meets the eye in the hoodie horror cycle as these films also offer, albeit in a roundabout way, a much more subversive discourse, not only exposing and critiquing many irrational fears of contemporary Britain but also questioning the society that produces this type of antagonistic representation.

\section{"For some, the hoodie represents all that's wrong about youth culture in Britain today." (David Cameron 2006)}

2 Youths who recently became known as hoodies have been present in British cinema for at least two decades, often represented as juvenile delinquents in pseudo social-realist dramas. Yet, resorting to more extreme genre films, especially since the mid-2000s, has led to an emphasis on their supposedly evil nature. Hoodie horror films generally present these young people as amoral and bloodthirsty monsters. The creation of their enemy image was greatly facilitated by their general physical appearance and place of residence. Ubiquitous hooded sweatshirts and tower blocks are indeed just two of the main cinematic signifiers of that supposedly rising and uncontrollable threat taking over Britain.

3 The symbolic power of the hood with its heavy historical or mythical connotations (the Grim Reaper, the Four Horsemen of the Apocalypse, the Ku Klux Klan, etc.) may explain why it became a synecdoche for the person wearing it and endowed with such evil qualities (McLean 2005). ${ }^{2}$ With its promise of anonymity and mystery, the hood facilitates othering as, by hiding the face of its wearer, it makes his/her identification difficult and dehumanises him/her. ${ }^{3}$ Hoodies are thus recurrently presented as subhuman (in a process of animalisation) or superhuman (in a process of demonisation). Their human aspect (Eden Lake, The Disappeared, Cherry Tree Lane) makes way for more fantastic/supernatural portrayals that reinforce the use of animal/ monster metaphors in dialogues (Heartless, F., Citadel, Community). Because of the possibilities offered by genre films, the often-claimed feral nature of these creatures is sometimes taken in a literal sense. Hoodies are often silent, speak a language that is barely comprehensible or even express themselves using screeching, growling, roaring or grunting noises (F., Harry Brown, Heartless, The Disappeared, Citadel, Community) maybe 
because some are presented as illiterate (Cherry Tree Lane) and others, although they do not "turn", clearly evoke werewolves who smell their prey before pouncing (Community with its day/dusk transition into beast mode). Some remain dark figures crouching, moving swiftly and jumping about like apes or felines, often shot in a corner of the frame, usually in the background, sometimes out of focus. The occasional close-up of their hands holding various weapons manages to link them to the human species $(F$.). With their shining canine or reptilian fangs, they are typically portrayed like hounds hunting in packs. ${ }^{4}$ They can even literally be presented as squirming monsters, infected mutants or demons, all the more as some wear clawed gloves that turn them into hybrid creatures (Community, Citadel, Heartless) (Figure 1). ${ }^{5}$ Building on the representation of youths as folk devils, some of them appear like Lucifer's minions associated with his horns (Citadel) or hellfire. Hoodies are shot in close-up amid the blaze caused by petrol bombs, opening their arms defiantly (Antisocial Behaviour, Harry Brown, Heartless). Flames reflect on their shades as they laugh maniacally trying to burn up their victims (Eden Lake) that they often lock up in bins (F., Comedown, Attack the Block). Their war wounds (cuts, scars and tattoos alluded to or shown in Cherry Tree Lane, Heartless, Community) give the impression they can survive any attack, like the devil himself.

Figure 1. Animals and mutants

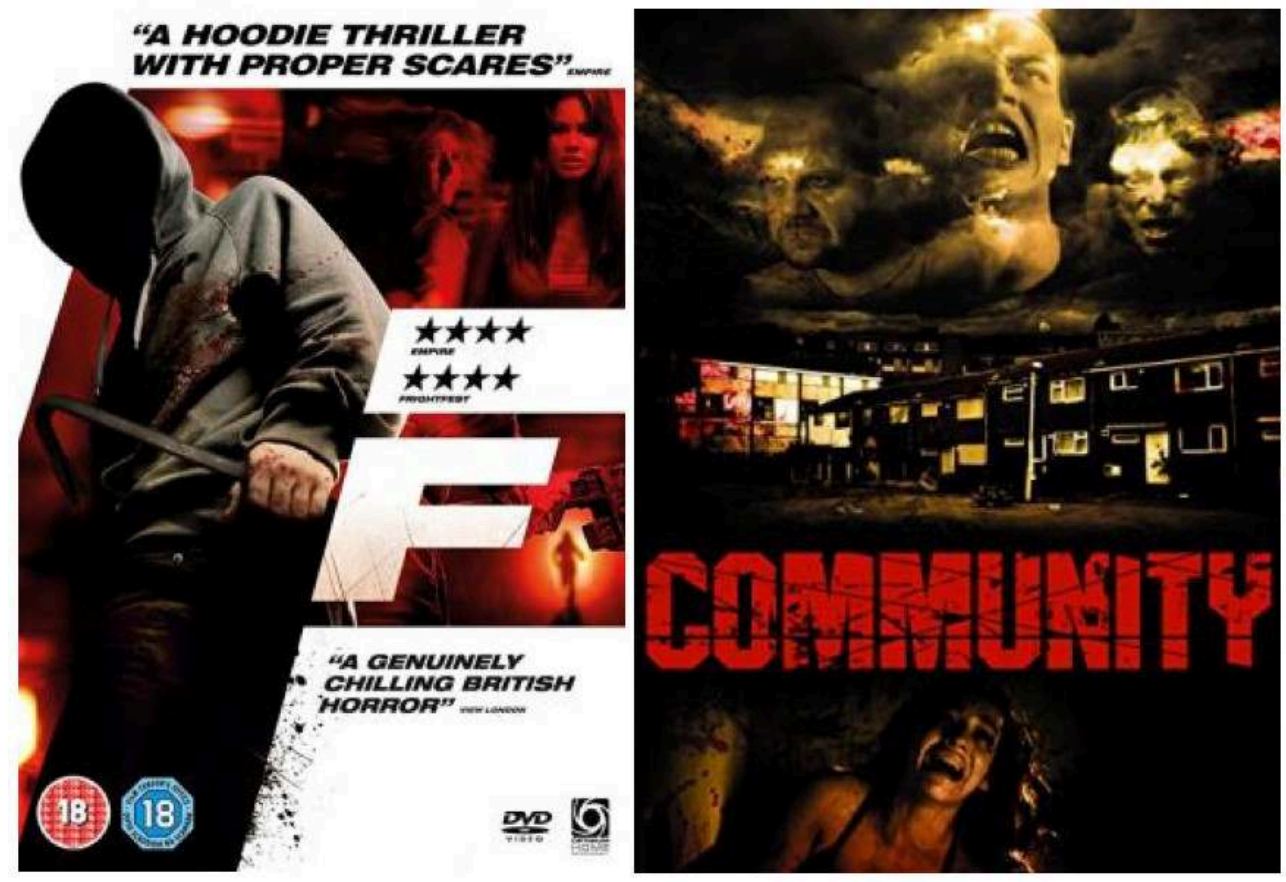

Source: IMDB

4 Hoodies, being demonic, are seen as contributing to the general collapse of society in a sort of teen-related apocalypse; some films seem especially concerned with their everdecreasing age (Citadel, Community and their children reminiscent of The Village of the Damned, with their Roswell t-shirt and "alien" stare, or the dwarfish Little Red Riding Hood of Don't Look Now). Mingling violence and childishness, they offer a demystifying view of childhood innocence; this is often underlined by soundtracks featuring children's songs or lullabies being hummed and mixed with more eerie/uncanny tunes 
(Eden Lake, F.). Overall, the feeling that adults have willy-nilly lost all authority over youths pervades (Antisocial Behaviour, Eden Lake, F., Cherry Tree Lane, Citadel). Early on in their lives, hoodies seem run by a killing instinct that they usually focus on animals (Eden Lake, Comedown, Community, Attack the Block) before turning to human beings. They then prey on strangers (Eden Lake, Cherry Tree Lane, Community), but also on their neighbours and their own kind (Antisocial Behaviour, The Disappeared, Heartless, Harry Brown, F., Tower Block, Attack the Block, Citadel, Comedown), especially the weak - kids, the elderly, the disabled, women. Roaming the streets on their BMX bikes (another signifier of teen terror in Eden Lake, Harry Brown, Attack the Block, The Disappeared, Community), they attack all fundamental institutions, like the family, schools, and the police. Contrary to popular belief, hoodies are found everywhere, in urban as well as suburban or even rural environments depicted as a wilderness (although in Eden Lake the woods are never shot in a scary way as if to emphasise that evil roams in paradise); this can suggest the idea/tabloid mantra that hoodies have indeed taken over the UK (Anonymous 2005; Murray 2008) and that "nowhere is safe" as the protagonists of Heartless keep repeating. Their supposedly invasive nature might explain the use of home invasion conventions (Cherry Tree Lane, Citadel, F., Comedown). Their ominous and sprawling threat is, for instance, symbolised in Cherry Tree Lane first by the opening creeping track in on the front door of the targeted house, then by the extreme closeups of various parts of their bodies and faces throughout the film, which reinforces the clinical and claustrophobic style of the shooting as well as the monstrous aspect of these youths. Presented like poachers and parasites, they make themselves at home in their victims' house. The recurrent shot of the front door in Citadel symbolises the hero's fear at the idea of hoodies entering (their shades reflect on the glass then on the teapot), and he ends up locked-up in the bathroom as various sounds indicate the house is being stormed.

Figure 2. Cherry Tree Lane Trailer

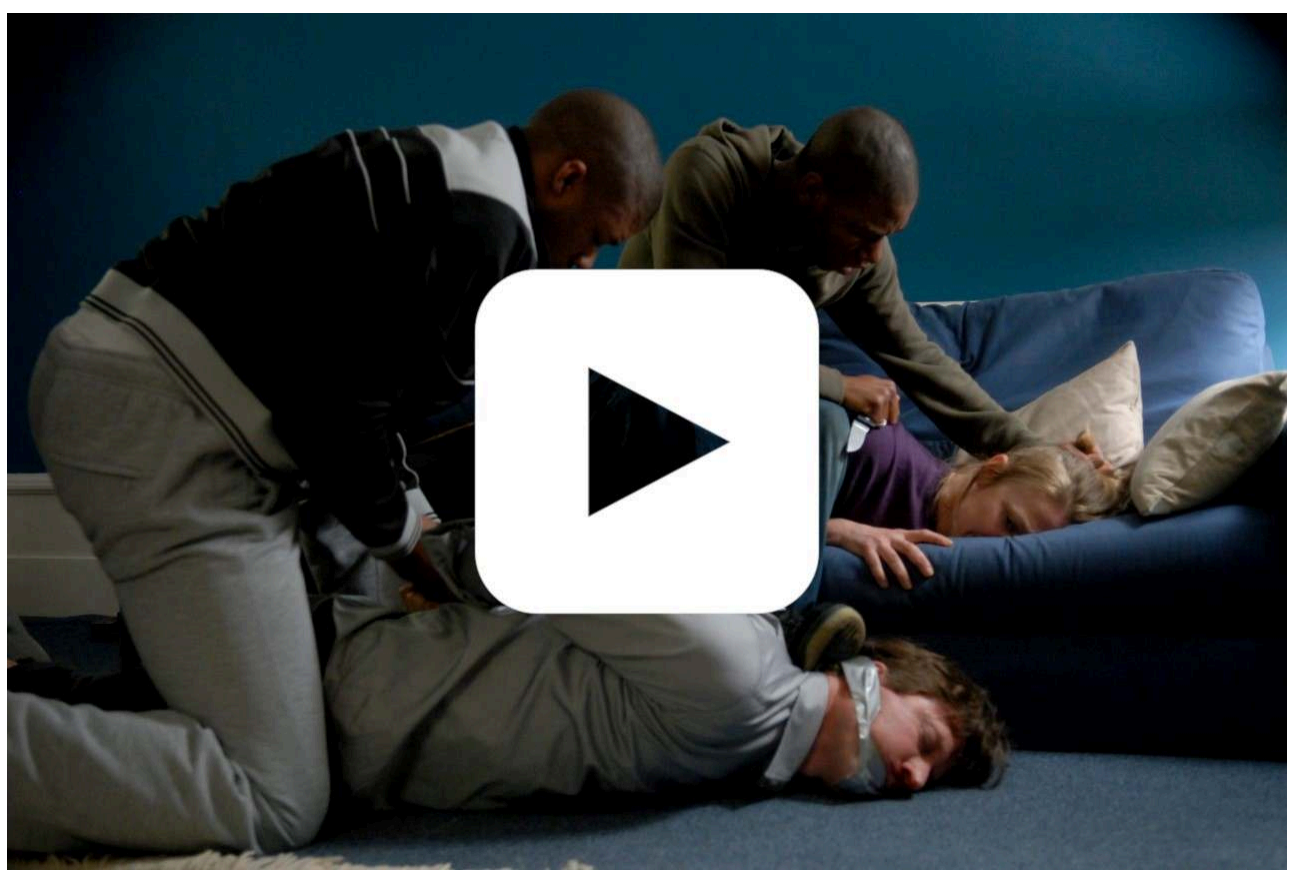

Source: https://www.imdb.com/video/vi2695629081?playlistld=tt1468829\&ref_=tt_ov_vi 
5 These gangs of predators are all the more frightening as they seem to embody what Coleridge referred to as "motiveless malignancy" and can be likened to ultimate evil (confirmed by Lucifer himself in Heartless "I'm like the patron saint of random violence"). Most films picture hoodies as a bourgeois nightmare or neighbours from hell, with vulgar gangs of teenagers harassing peaceful adults for no other reason than pure sadistic pleasure (Eden Lake, F., The Disappeared, Harry Brown, Tower Block) and for whom gang assault is a sort of house party (Cherry Tree Lane). Constantly looking for trouble, they even drive some neighbours mad because of their pestering power (Antisocial Behaviour, Heartless, Citadel, Comedown). Youths who get arrested endlessly insult cool-headed officers but never wish to comment on their evil deeds deemed to be entertainment or fun by the latter (Harry Brown, Heartless). One of the intertitles of the trailer for $F$. implies that there is "no reason" to explain the killing spree organised by the hooded gang, which is confirmed by the fact that the viewer never really gets to see or hear them in the film. The flippancy, mood swings and unpredictability of hoodies reinforce their amoral terrorising power (they can suddenly feel chatty with their tiedup victims before deciding to rape them, or offer them orange juice before kicking them in the face as in Cherry Tree Lane). The psychotic profile of some youths is highlighted by a low-angle close-up of their hateful faces, as they hysterically beat up their victims or, on the contrary, by their expressionless, desensitised faces as they watch the victim being punched, kicked to death or raped by their mates (Eden Lake, Tower Block, Cherry Tree Lane). High-angle long shots obviously inspired by CCTV tapes shown on television are used in Harry Brown. The hoodies' fascination for violence shows through recurrent close-ups of the shiny blades of their Stanley or flick knives (when they do not use axes as in Cherry Tree Lane or dirty syringes as in Citadel) and through their screen addiction. When they are not watching gangsta rap videos (Cherry Tree Lane) or playing violent videogames (Community), they film wobbly shots of their victims on their mobile phones (Harry Brown) because they are especially fascinated by their own evil image that they proudly advertise through the use of social media. Hoodies thus ironically reclaim their enemy image through happy slapping videos (Eden Lake, Antisocial Behaviour, F., The Disappeared, Harry Brown, Heartless, Tower Block) or snuff movies (Community).

6 The other key signifier of hoodie evil is the place they usually live in. Council estates, especially their tower blocks, have become synonymous with urban decay and social deprivation, as explained by the intertitles of Tower Block, so much so that the student in Attack the Block is surprised to find out that the nurse he has just met lives on the estate he only visits to buy drugs; council flats are usually seen as the place where social failures - long-term unemployed, "junkies and geriatrics" - end up (The Disappeared, Citadel). The isolation of these "abject border zones" or "antisocial spaces" (Tyler 2013: 160) from the rest of the city is sometimes symbolised by a pan from central London buildings to the eastern London tower block that disrupts the skyline (Comedown) or a crane shot of the cityscape gradually narrowing in on the estate (Heartless). Such techniques establish a dichotomy between "Landmark London" (Brunsdon 2007: 21-56) and "Horror London" (Hutchings 2009). Council estates, like Aylesbury or Heygate, and tower blocks have been used a lot in these films for their cinematic quality. ${ }^{6}$ Medium or long shots of these giant monoliths seemingly erected on never-ending wastelands are sometimes enough to evoke a sense of awe without hoodies being even seen on the premises (Citadel). Their shadows or reflection suggest 
the impact they have on residents' lives (Citadel, The Disappeared, Comedown). They have undergone a similar process of demonisation and, despite their ironic names (Serenity House in Tower Block, Cendrillon House in Heartless, Edenstown in Citadel, Mercy Point in Comedown), they are depicted as "terrible places" (Clover 1987: 197-8) or "uncanny landscapes" (Hutchings 2004)7. Some sink estates even seem fertile grounds for the roaming of usually maleficent supernatural forces (Heartless) as signalled by the crows flying above some of the buildings (The Disappeared), the fact that the few buses still running stop serving the area as early as 4 or 6 p.m. (Community, Citadel), or the overcast sky (Comedown, Community). Whether they are real locations or the result of special effects that make them look worse than they actually are (which is telling enough about the council horror fantasies and nightmarish visions developed by British media), ${ }^{8}$ they have become urban legends (as the opening street interview intercut with a series of shots on a rubbish-strewn estate shows in Community) and their walls look as leprous as the skin as some of their hosts (Citadel). The drabness of estates is further stressed by the yellow/green or desaturated blue/grey photography (Harry Brown, Citadel, The Disappeared, Tower Block). Tower blocks are either filmed in static lowangle shots or descending tracking-shots by night to reinforce the ominous look of the brutalist architecture of the building with its exposed concrete volumes and strong geometric lines (Harry Brown, Heartless, Attack the Block, The Disappeared, Tower Block, Citadel, Comedown) (Figure 3). The dimly-lit alleyways, the maze of stairwells and corridors, the flickering neon-lights and erratic lifts add to the eerie atmosphere of the place (Heartless, Citadel, Tower Block). Most decrepit blocks being half empty and condemned to demolition, they make the area look like a ghost town or a postapocalyptic world in which mankind is returning to a neo-barbarian state (Tower Block, Citadel, Comedown, Community). Dead silence can nonetheless be interrupted by various forbidding noises (car alarms, screams, barks, gunshots, distant sirens). Derelict estates symbolise a poverty trap, an interpretation which is acknowledged by the police (Harry Brown), leading their residents to degeneracy (Citadel, Community). Sometimes the poisonous nature of that environment is literalised, like the green fungus growing on the walls of the tower block that is being licked by the gang (Citadel, see also the street interview in Community). The places that hoodies colonise, usually the weed room (a flat used to stash or grow cannabis), a basement or a subway, but also children's playgrounds (The Disappeared), are depicted like dens where all sorts of trafficking take place, real mouths of hell that need to be sanitised so that the neighbourhood can live again (Harry Brown, Citadel, Comedown, Community).

Figure 3. High-rise hell 

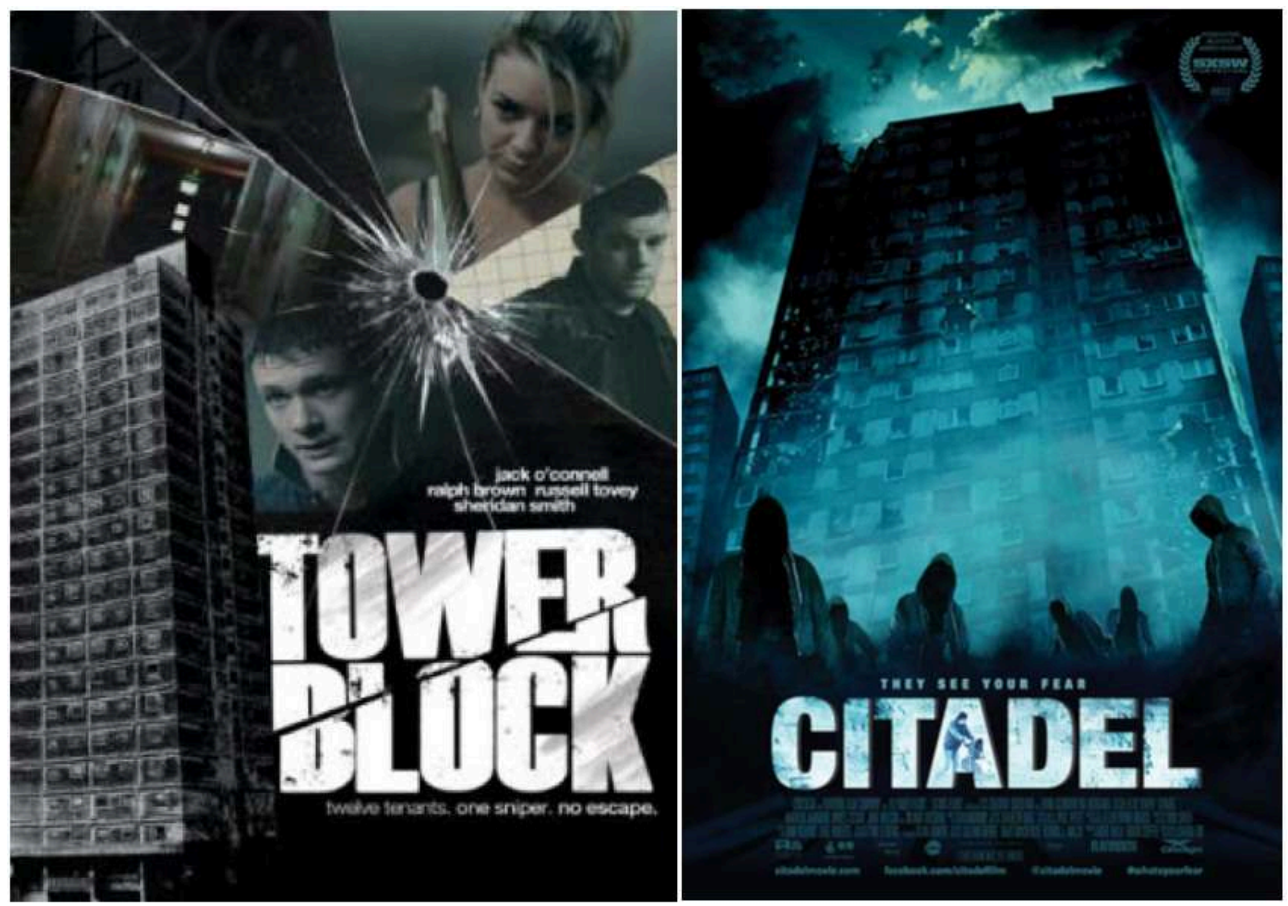

Source: IMDB

\section{"Those thugs we saw last week do not represent us." (David Cameron 2011)}

7 Because it seems to give credence to a social stereotype initially developed by the British press, hoodie horror has sometimes been castigated for its perceived conservative, reactionary and/or racist overtones (McNulty 2016; Newman 2011: 476). Allegedly feeding on and fuelling moral panic, it may perpetuate clichés, all the more so as these films tend to mix a social-realist type of character and setting with typical exploitation genre codes, which can further blur the thin boundary between reality/ actuality and cinema/fantasy for spectators (Walker 2016: 96, 107; Lönroth 2014: 6-11), hoodies existing "as much as a truism as a trope" (Brooks 2008). This might explain why the right-wing tabloid press has usually supported these films because it believes they corroborate its vision. Eden Lake and Cherry Tree Lane were praised for their supposedly gritty realism or documentary aspect, while they are typical backwoods or home invasion fare (Tookey 2008; Simpson 2012: 269; Walker 2016: 95). The commercial success of some of these films is based on the perceived authenticity of their villains ("real, realistic horror" are common comments made by both the critics and the directors of these films), ${ }^{9}$ the feeling that danger lies just round the corner, an argument used by the film producers as part of their marketing strategy (Walker 2016: 87,90 ) that builds on teen boys as a "toxic brand" (Bawden 2009). ${ }^{10}$ With its oozing class contempt and stigmatisation of the excluded (Clarke 2013; Hatfull 2013), hoodie horror has been accused of peddling questionable ideologies, relying on pseudo-sociological theories in vogue amongst political and media circles despite being debunked by social sciences. ${ }^{11}$ By putting forward cultural or behavioural rather than structural causes to account for hoodies' purported antisocial behaviour, the subgenre may appear like a by-product of neoliberalism that seeks to reclassify certain sections of the population 
as revolting subjects (Tyler 2013: 73-4, 211-4) in order to avoid the indictment of the economic and social policies that could be responsible for it. Hoodie horror is thus deemed to deny the wider social context in order to better essentialise evil through the construction of a new folk devil, the hoodie being used as a smokescreen obfuscating class consciousness and struggle (Featherstone 2013: 181; Blake 2012: 142; Lönroth: 13, 18).

Some elements in these films apparently validate a class bias. The enemy image born out of the symbolism of the hood is worth exploring further. Although today many if not all youths tend to wear the same style of clothes, the hooded sweatshirt has become associated with the dress-code of potential criminals on and off screen. ${ }^{12}$ It scares "decent" citizens - in other words middle-class people - because it unconsciously signals a male working-class identity. The few middle-class hoodies seen in these films are never perceived as a threat (F., Attack the Block). This distinction between hoodies is evidenced by various class-markers such as accents (Multicultural London English or northern/Midlands vs posh accents), and musical tastes associated with a type of attitude (gangsta/dirty rap vs reggae/old school rap). As James Watkins, director of Eden Lake, explains "if you had a bunch of public school kids in blazers, it just wouldn't be that scary" (Graham 2009). Hooded youths, the new incarnation of evil in British horror films, are thus a roundabout way of expressing age-old fears of a disenfranchised working class that some call underclass.

Figure 4. Generation wars

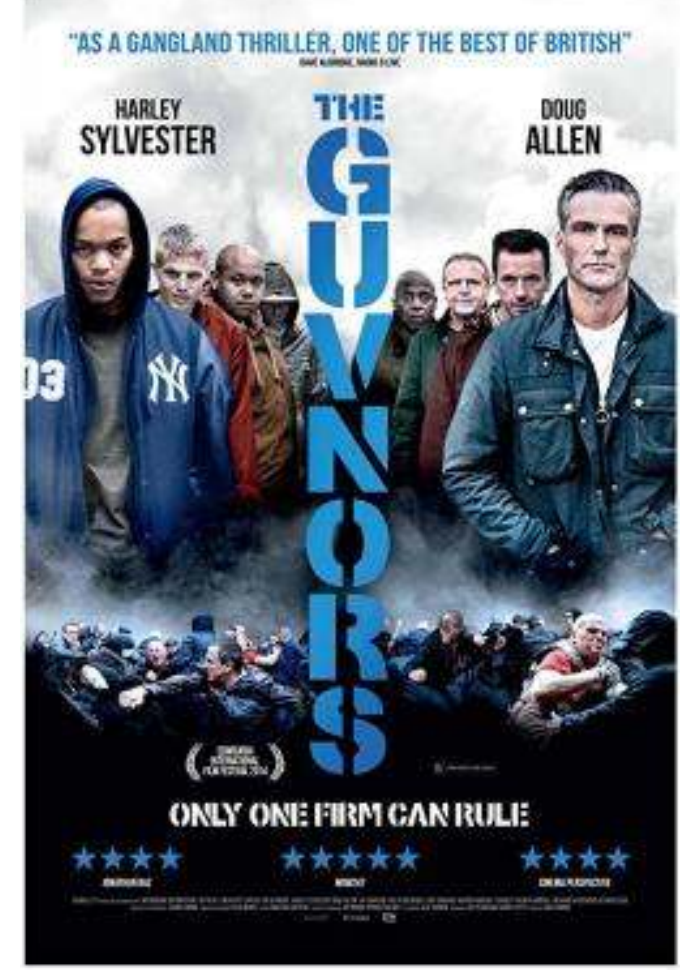

Source: IMDB

9 The depoliticisation of social antagonisms may explain why many of these films rechannel what is often a class confrontation into a virility contest or a father complex between the adult victim and the young predator (Eden Lake, Cherry Tree Lane, F., Citadel, 
The Guvnors) (Figure 4). The fear hoodies generate has to do with the performance/ performativity of masculinity - what it takes to be or act like a man though not necessarily in a sexual way - since the working-class one is perceived as hypermasculine while the middle-class one, by comparison, seems to verge on demasculinisation and effeminacy causing anxiety, violence and class misunderstanding (Eden Lake, Cherry Tree Lane, F., Citadel, Attack the Block). Combined with a reference to the myth of Cronus, the subgenre may call for the restoration of the power of adult, often middle-class, males whose hegemonic rule has been increasingly undermined in a youth-fascinated (and women-empowering) society. A real man must protect his wife/family by embodying the law seemingly symbolised in these films by the ability to kill a hoodie.

In hoodie horror, the feeling of declining authority is linked to the theory of the absent father and, more generally, to the concept of the family. The idea of a transgenerational pattern of poverty and crime, the underlying assumption that "problem" or "troubled" families are the root cause of hoodies' malevolence is definitely present as an echo of recent media (Ware 2009) and political campaigns. ${ }^{13}$ Gangs often reproduce a family hierarchy (with "youngers", "olders" and "the big man") because their members are born into families in which mistrust of the police is a secular tradition and being jailed a source of pride (Eden Lake, Harry Brown, Cherry Tree Lane, Attack the Block, Community). Hoodies' families are presented or assumed to be dysfunctional: broken homes run by ineffectual single mothers living in neighbourhoods where many adults are unable to exercise their prerogative because they are drug-addicts or alcoholics (Cherry Tree Lane, Citadel, Community); clans led by abusive parents with a brutal/psychotic/perverted history which might explain their offspring's obnoxious behaviour (Eden Lake, Harry Brown, Community, The Disappeared). With an increasing spatial segregation since estates have become no-go areas, the ageold idea of a residuum is also present (Welshman 2013: 15-34, 57), albeit modernised as a so-called new underclass, in other words a social-problem group living in isolation from mainstream society, transmitting a culture of poverty and, let us say, alternative moral values from generation to generation that look like carbon copies (Eden Lake, Tower Block, Community). The songs played or sung ("Respectable" in Eden Lake, "Jerusalem " in Community) ironically proclaim both the hedonism and pride of these disreputable tight-knit communities.

11 Many films including a sub- or super-human dimension to emphasise the monstrous character of hoodies also echo some of the old eugenic theories of the early twentieth century revived by Charles Murray in the late 1980s (Welshman 2013: 161, 163-184) by presenting these new villains not only as culturally but also biologically different. Citadel's mutants include children and even babies, as if to suggest that youths living on estates are doomed from the start and a lost cause. The degeneracy and/or contamination imagery typically linked to the representation of the poor through the decades (Welshman 2013: 11, 16, 26, 57-8, 122, 167-8, 197) and typical of the backwoodsinspired genre with its inbred, cannibalistic, infected mutants and freak-show (Citadel, Community), ${ }^{14}$ leads some of these films to advocate a dubious discourse on how to deal with the hoodie problem. Unlike eugenists who promoted the segregation and sterilisation of the poor to contain the disease (Welshman 2013: 69), some films pathologise hoodies to exterminate them. They seem to endorse retribution and resort to social cleansing showing their annihilation either by a vigilante/avenging angel 
(Harry Brown, Tower Block, Comedown) or by a purifying fire (Heartless, Citadel) (Figure 5). ${ }^{15}$ It also allows them to debunk the liberal theories put forward by other sociological schools that try to explain or even sanction hoodies' violence and, consequently, are deemed complacent. This is the case in Citadel and Community in which, respectively, the nurse and the student film-makers die butchered by a pack of depraved hoodies after complaining about the demonisation of these poor young estate kids that are just in desperate need of love and attention, maybe an ironic allusion to the "hug-a-hoodie" moment after David Cameron's speech in 2006. ${ }^{16}$ The opening of Eden Lake ambiguously alludes to the debate generated by the Blair government's policies. The radio pundits do not see fining parents as an effective solution but the blithe attitude of the couple laughing at those who live in hoodie fear is put into perspective by their doom, a particularly gory case of tragic irony.

Figure 5. Social cleansing and scorched earth policy
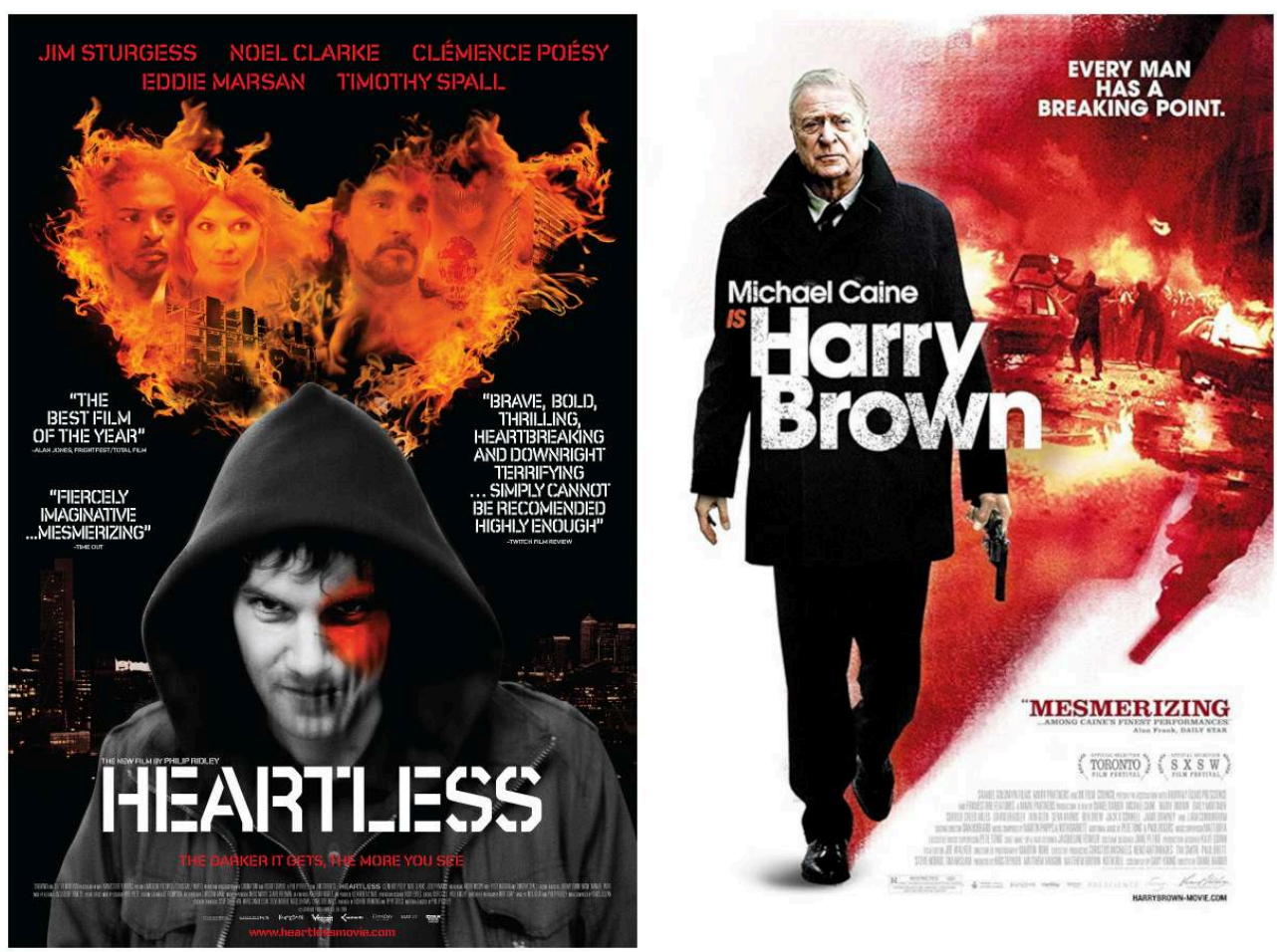

Source: IMDB

These various ideological undertones may be why these films were sometimes derisively tagged as "horror for Daily Mail readers" (McNulty 2016), "hysterical Daily Mail editorial[s] made cinematic flesh" (Donald Clarke 2013) or "a Daily Mail reader's wet dream" (Tilly 2008), since their "deliberately inflammatory" style and "moralistic binary" (Walker 2016: 86) seem to illustrate so perfectly the most sensationalist headlines published by that newspaper at the time of the 2011 riots. For example, one of its star columnists wished for looters to be clubbed like baby seals after abolishing the "Yuman Rites Act" (Littlejohn 2011). ${ }^{17}$ Viewed in this light, watching some hoodies being eventually butchered by their victims may be interpreted as a debatable cathartic process, illustrated by gory close-ups of their dead or dying bodies (Eden Lake, Harry Brown, F., Citadel, Comedown). These films also clearly echo some of the political speeches or statements of the last two decades, hoodies standing for the "social abject" and the 
"politics of disgust" (Tyler 2013: 21, 162) i.e. the culturalisation/biologisation of poverty and inequalities under Blair's and Cameron's governments. ${ }^{18}$ Following this thread, hoodie horror does appear as a major contributing factor to the reinforcement of the enemy image of young working-class males.

\section{Hoodie Horror. Beyond the "Poverty Safari" (Darren McGarvey 2017)}

13 Although hoodie horror can be put forward as a discriminatory subgenre, this interpretation has to be mitigated. Owing to the conventions of the genre, all films belonging to this sort of cycle have to reinforce the horrific nature of hoodies. If they tried to explicate and contextualise, i.e. make the causes of hoodie evil explicit, they would undermine the horrific nature of the subgenre and turn into more social-realist films. ${ }^{19}$ Some films nonetheless allude to the usual reasons given to explain hoodies' antisocial behaviour such as gang-related activities and peer pressure (Cherry Tree Lane, Comedown, Eden Lake, Heartless), and most directors and scriptwriters insist on the roundedness of their characters to avoid the tabloid feral carbon copy effect ${ }^{20}$. Instead, one can question the very existence of that cycle of films and what the choice to resort to horror to depict something that initially stemmed from a sociological context tells us about the state of contemporary Britain. ${ }^{21}$ Like all genre films, hoodie horror is selfaware and plays with its codes and conventions to subvert and question the enemy image it gives to hoodies. The conclusion is often that the source of horror lies not in the hoodies themselves, but in the eye of the assumed middle-class beholder (aka the implied viewer). To paraphrase Darren McGarvey (2017: xx, 187-8), hoodie horror does not invite the viewer to "a safari of sorts, where the indigenous population is surveyed from a safe distance for a time, before the window on the community closes and everyone gradually forgets about it". The prism of horror is chosen to make sure the viewer does not forget and is used as "an attempt to hold a mirror up to" his/her assumptions. Repositioning the audience is thus also a key aspect of that subgenre to reveal its true "political unconscious" (Blake 2012: 6).

Hoodie horror films do not just reflect the media hysteria of the time; they put it into perspective in explicit and implicit ways. Some instil doubt as to their hyperbolic representation of hoodies since the hero is a disturbed, borderline character, who suffers from psychological trauma or mental issues - in other words, he is an unreliable narrator which enables the film to debunk its own narrative with visual or sound motifs as well as multiple ironic details (Antisocial Behaviour, Heartless, Citadel, The Disappeared). The recoding/decoding of socially realistic elements such as gangland warfare and drug addiction into fantasy/horror genre "evil" tropes calls into question the doom-mongering discourse heard. Some films even clearly point out the role of the media and so-called experts in fostering moral panics that increase the feeling of insecurity and sometimes lead law-abiding citizens to madness, paranoia or vigilantism (Heartless, F., Harry Brown). Newspapers and television are seen as channels for dominant discourse, namely that of the ruling class (Monbiot 2011; Welshman 2013: $140,169,181,231$ ), suspicious towards the working class (The Disappeared). They use people's prejudice in their reports but also reinforce them (Heartless, F.) by obsessing over gang-related crime (Heartless) and mixing sensationalist reports and lighter news (Antisocial Behaviour, Harry Brown). That may be why some gangs become obsessed with 
their image in a celebrity culture (Eden Lake, Harry Brown, Attack the Block) that feeds on violent web videos (Heartless). Community, with its mockumentary approach, appears like a meta hoodie horror film, as the Grand Guignol foregrounds and deflates the usual clichés of council estate horror stories found in both sensationalist media and films. Its combination of occasional social commentary and leering voyeurism makes it a perfect product of its time. As for sociologists' grandiloquent and apocalyptic theories about youth crime on TV, they, too, have to be taken with a pinch of salt since the most zealous one is called Charles Perrault - the $17^{\text {th }}$ century French author of children's fairy tales - as if to say that, letting his imagination run wild, the pseudo-sociologist may only be telling tales (Heartless). These films thus seem to offer a somewhat contradictory discourse in a sort of nod to the spectator.

Like A Clockwork Orange, some films establish parallels between different types of horror that can influence their final interpretation; the fight for survival concerns not only the hoodies' victims, but also the hoodies themselves when they are confronted with a worst enemy/super-predator. Other films introduce nasty or not particularly likable hoodies before opposing them to a killer or a psychopath, or even real demons and aliens from outer space, which tends to downplay their crime or offences and supposed monstrosity (Antisocial Behaviour, Cherry Tree Lane, The Disappeared, Tower Block, Comedown, Attack the Block). These films also include an ironic twist as the killer or psychopath turns out to be a person thought above suspicion, a respectable citizen, a decent family man who starts out being a victim and ends up committing more reprehensible crimes than hoodies, a case when the symbolical father's wrath and restoration of his power go too far (Figure 6). These films thus confirm that, whatever his/her class, any human being has a potential for evil and barbarism. ${ }^{22}$

Figure 6. One villain may hide another
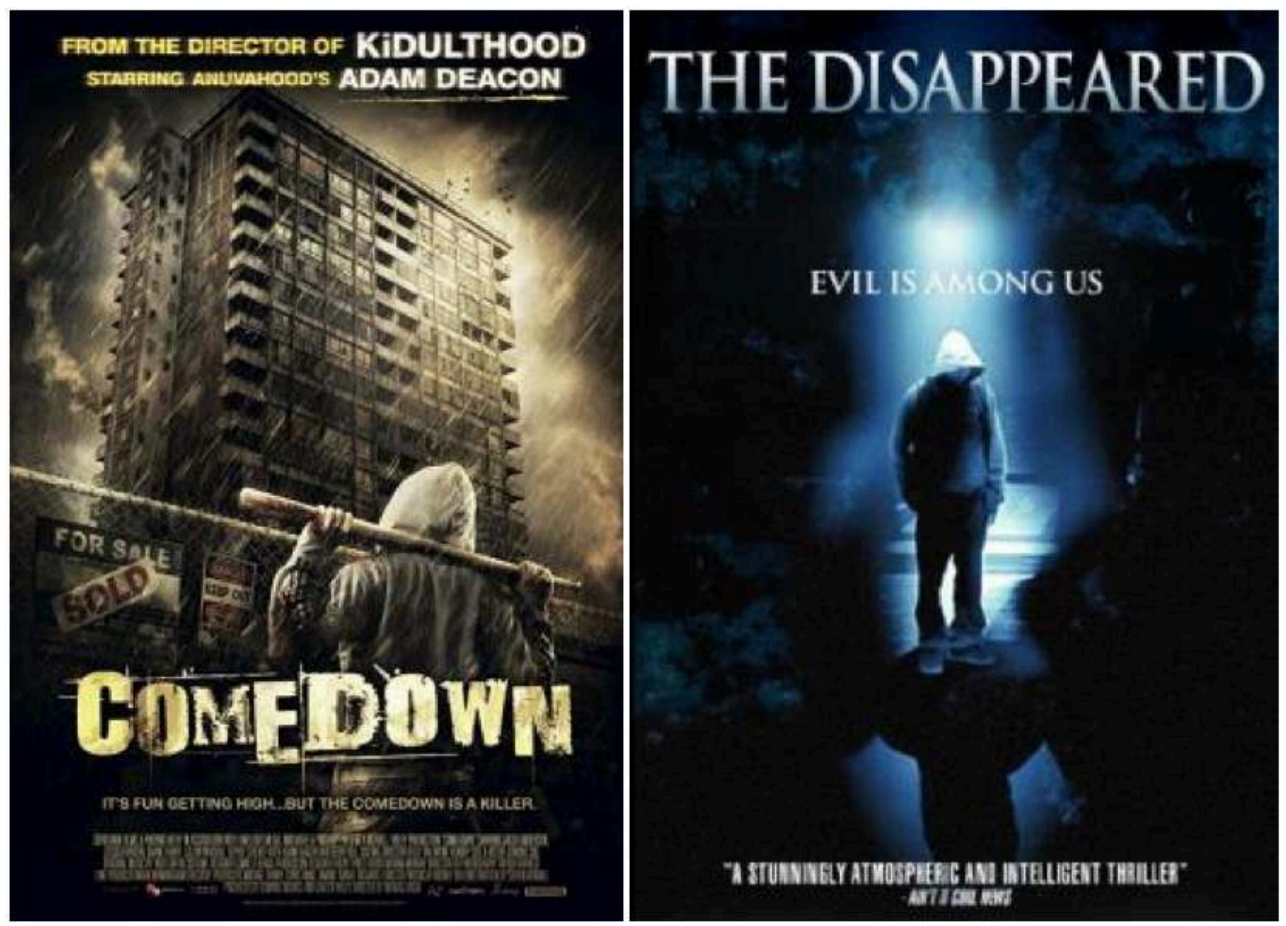

Source: IMDB 
Accusing hoodie horror of classism is missing the point because class prejudice goes both ways. All films mock lecturing self-righteous citizens that are prone to despise hoodies but prove to be far from perfection. They implicitly question Middle England's beliefs and debunk its class arrogance since the hoodies' victims are often presented as rather unsympathetic characters that are just as individualistic, selfish and flashy as their persecutors. Middle-class parents are completely unaware of their children's drug habits (Cherry Tree Lane) or do drugs themselves (Community). Their educational values, like their thwarted desire for corporal punishment, are hypocritical (Eden Lake). Domestic scenes reveal their incommunicability (Cherry Tree Lane, F.). Middle-class people can be showy and materialistic (Eden Lake). Their progressive and enlightened stance is delusional verging on complacency (Eden Lake) or sheer cynicism (Community). As mentioned, some films respond to the home invasion conventions as if to better symbolise their supposedly sprawling threat. Yet it is the middle class's constant encroachment and will to impose their presence and lifestyle everywhere that is sometimes the cause of their trouble. Eden Lake and Community can be viewed as inverted home invasion films in which Middle England's repeated legal and symbolic trespassing and double standards reveal its semiconscious patronising attitude and culture of entitlement (ironically so often denounced when related to the underclass) born out of its belief in class privilege (Figure 7).

Figure 7. Middle England's nightmare

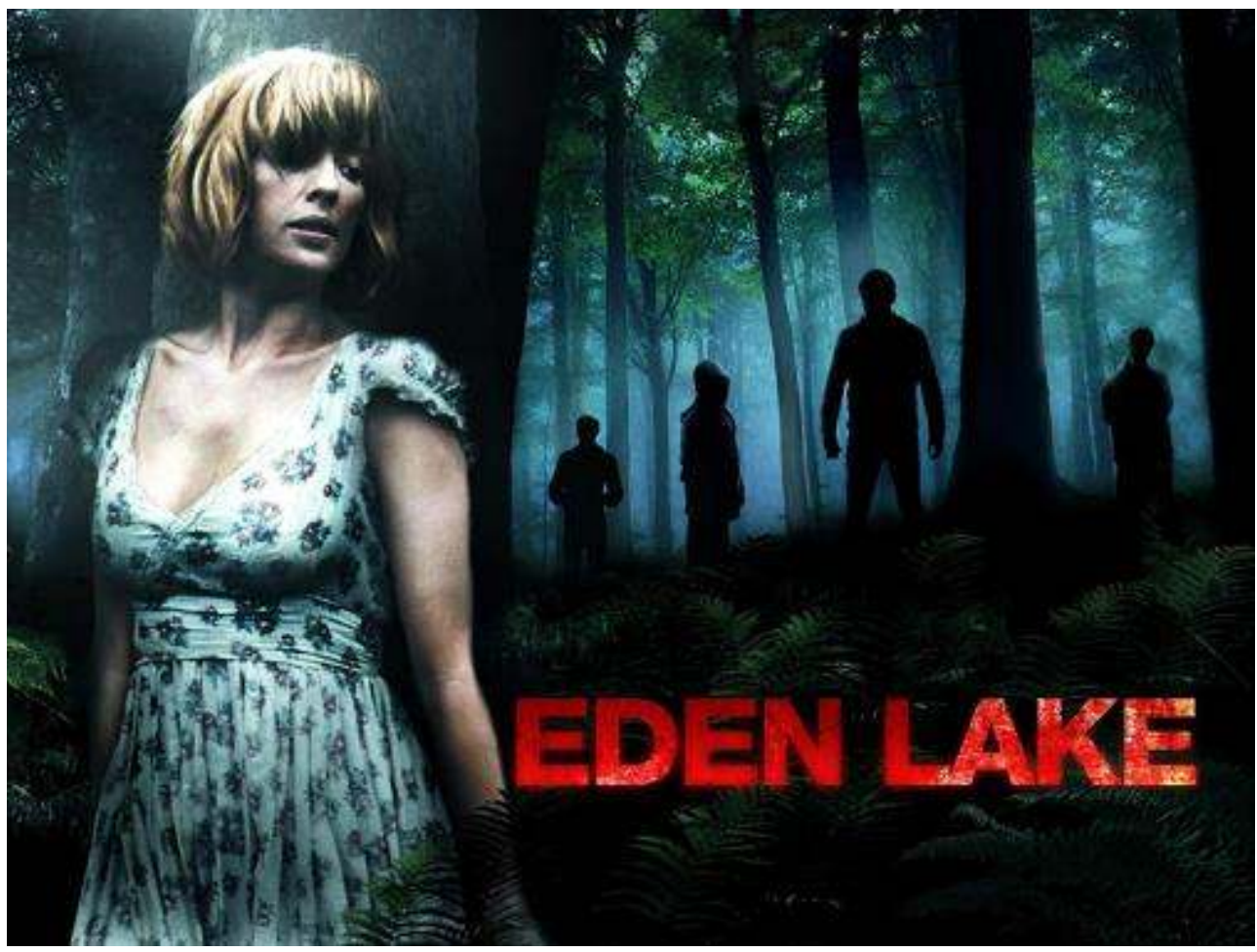

Source: IMDB

17 Besides challenging notions such as normal/normative and marginal behaviours, ${ }^{23}$ these films also show that the fear of hoodies and the general impression of moral collapse are due to another type of antisocial behaviour i.e. the passivity of citizens when witnessing a crime or intimidation, which can be interpreted as the result of extreme individualism; as long as you are not directly involved, you remain careless 
(Antisocial Behaviour, Eden Lake, Harry Brown, F., Tower Block), as shown by the close-ups of hands closing locks, switching off lights (Tower Block) or long shots of whole neighbourhoods watching a beating impassively (Harry Brown). ${ }^{24} \mathrm{~A}$ non-committal attitude while maintaining a superiority complex is criticised. Those who do nothing or act selfishly end up being victims of hoodies themselves. Those who adopt an extreme attitude and become a law onto themselves are shown like a dead-end (they usually die or are clearly presented like demented people). Conversely, citizens who feel a moral duty to intervene and maintain some sense of neighbourliness in the community survive as the final boy or girl (Tower Block). The expository intertitles of Tower Block seem to make a link between the decline of the feeling of community and the rising crime rate on estates. The slightly low-angle shot (35') showing a united front of the residents against their extortionist implies that the power balance can be shifted. Preventive neighbourliness is also assumed to be able to put an end to the scapegoating of the monstrous other because it suppresses fear (a message fully exploited in Attack the Block). The most shocking films may eventually be the most ironic. Citadel which seems to advocate social cleansing clearly mentions several times that the hoodies only prey on those who fear them. Lucifer in Heartless admits that his power "don't work unless you're scared". The hero and spectator are thus invited to choose the best attitude to adopt, either giving in to or overcoming their fear. ${ }^{25}$

Ultimately, these films indirectly advocate the necessity for people from all walks of life to coexist because they show that class hatred and the socially segregated society it creates lead nowhere, i.e. to social horror. ${ }^{26}$ Depicting the killing of youths may be cathartic to some, but it is also awe-inspiring because of what it means about the relationship between generations and social classes in the UK (Antisocial Behaviour, Eden Lake, Cherry Tree Lane, Comedown, Harry Brown, The Disappeared). Hoodie horror films echo Thomas Hobbes's life in the state of nature. However, rather than being a simple nod to declinist supporters, they implicitly ask the question of why social classes have become so entrenched. The culture gap is so wide that no communication is possible and mutual ignorance leads to brutal interaction (Attack the Block, Cherry Tree Lane, Tower Block, Community, Eden Lake). The antisocial society born out of this distrust and subsequent fear of random violence is exemplified by the rise of gated communities (alluded to in Eden Lake) ${ }^{27}$ and all the forever-delayed regeneration projects that often turn out to be gentrification schemes (Comedown, Citadel, Tower Block, Community), a clear symbol that classes refuse to mix because they become increasingly intolerant and that working-class heritage is being erased, which aggravates tension. The long shot of the beach (Eden Lake) featuring the two groups on each side of the frame symbolises their spatial proximity yet social distance. Only the dog is able to go from one group to the other.

19 Horror (etymologically a combination of terror and disgust) taps into our primal fears and spits at our faces what we do not want to see. ${ }^{28}$ Beneath the evil acts performed by hoodies, the real horror is how mainstream society, Middle England, has let down whole sections of the population and only sees its poor youths in terms of fear and rejection. That is why a former community centre can be turned into a weed room without any reaction from the authorities (Community); why police investigations after the abduction or the murder of children and teenagers seem to vary depending on the social background of the victims (The Disappeared, Comedown, Citadel). ${ }^{29}$ Films tend to show that working-class kids do not matter, or worse, are immediately suspicious in 
the eyes of the law (Comedown, Attack the Block). Interestingly, those who complain about being let down by the police are the first victims of gangs, i.e. council tenants (Citadel, Harry Brown, Heartless, Community). Many police officers indulge in the same class contempt as journalists, thinking council residents deserve their fate, refusing to understand why the hoodies' neighbours do not denounce them (Tower Block).

Given the lack of empathy, one may go as far as to wonder whether the spectator is really meant to root for any character in these films, whether the victims are necessarily people they should aspire to be because they cannot side with the hoodies, ${ }^{30}$ and even whether their downfall is not to be interpreted as a form of retribution. Horror often proves to be a moral genre in which actions have severe consequences ${ }^{31}$ and hoodies could be Middle England's nemesis or a reminder of Bossuet's paradox: "God laughs at men who complain of the consequences while cherishing the causes". ${ }^{32}$ The couple in Cherry Tree Lane and the mother and son in Heartless who think their mugging is coming out of nowhere are actually the collateral victims of their relative's involvement in a gang. Hoodies are therefore almost never an incarnation of ultimate evil. They obey a moral code, that of the underworld Middle England prefers to ignore. Beneath its moralising sheen, hoodie horror reconnects fear with a class antagonism that works both ways. Reverse snobbery pervades the speeches and jokes of many youths (Eden Lake, Attack the Block); they use middle-class smugness to their own advantage (Community) and despise middle-class characters that try to bond perceiving them like posh people slumming it for a laugh (Attack the Block) (Figure 8). The worst cases of assaults always target members of the middle class, notably the wife who arouses heinous fascination for what is normally inaccessible (Eden Lake, Cherry Tree Lane). Eden Lake ends on the gang leader wearing his victim's shades, looking at himself in a mirror before directing his stare at the camera (i.e. the audience) with an ambiguous smirk. The hoodies' violence may not be political but their anger is certainly not amoral or random. 
Figure 8. "Hoodie horror for dummies"

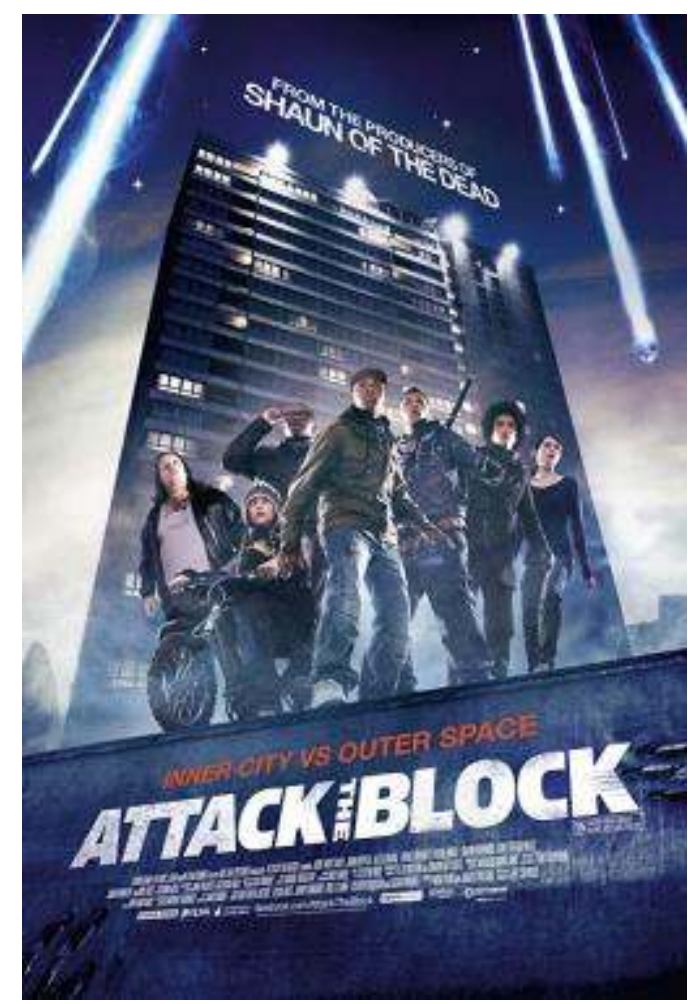

Source: IMDB

\section{Conclusion}

With a sociological subtext that is more nuanced than would seem at a first glance, the hoodie horror cycle is a complex mix that plays with, and exposes the fear of, contemporary British society. Unlike some "poverty porn" scripted-reality shows or sitcoms (Plunkett 2014), it is not just based on repetitive, often laughable, negative stereotypes so that eventually "the lie becomes the truth". ${ }^{33}$ The horrific nature of these films is intentionally used as a way to make spectators think about their fear and disgust (Simpson 2012: 269) all the more so as the choice of that genre enables directors to potentially reach other audiences than the usual social-realist converts or present the latter with a vision of youths they normally disapprove of. ${ }^{34}$ Demonising hoodies is a device to analyse Middle England's demons, touching on its fascination (attraction and repulsion) for young working-class males and the role it plays in the elaboration of an enemy image. Hoodie horror tries to act as a translator between social classes (McGarvey 2017: 188) calling on the audience for more empathy and less righteousness by exposing the distorted perception of many people on that subject. ${ }^{35}$ The best proof of the ironic dimension of the subgenre is probably Attack the Block because it makes the subtext of most of these films explicit. It is unique in that it manages to both humanise hoodies while keeping horror characteristics. By playing with the tropes of genre films while using comedy and black humour, it emphasises the sort of ironic distance or detachment that is often present but not necessarily perceived in more straightforward horror films. Underlining their typically exaggerated or hyperbolic representation, it destabilises middle-class prejudices on which the latter is based. Parody makes it clear 
that hoodie horror is not social realism, contrary to what some tabloids think. ${ }^{36}$ It acts like "hoodie horror for dummies" and lifts ambiguity as to the interpretation of hoodie horror films, i.e. whether they contribute to the elaboration of an enemy image by demonising hoodies or to the deconstruction of that image by giving flesh to the fantasies of some tabloids' articles to better expose them. ${ }^{37}$ Sending classes back to back to achieve that goal may be interpreted as cynicism yet it is also a way to reveal the ambiguity of British society. Hoodies have been targeted both by media and politicians as a minority of irredeemable creatures (not "us") yet an overpowering threat able to bring down a whole country. Hoodie horror illustrates the overblown nature of that marginal public enemy while positing that the pseudo-sociological alternative put forward by both politicians and media - a "classless commonality" (Welshman 2013: 181), i.e. an overgrown/oversized middle-class "us" vs a "hopeless chav rump" (Jones 2011: 139) - is a fallacy. ${ }^{38}$ Contrary to what some might think, this film cycle is not an intentional smokescreen designed to obfuscate class consciousness and struggle. Rather, it unknowingly reveals the general state of confusion of a society that has forsaken the language of class while it paradoxically still attaches great importance to social hierarchy. Defining social classes is difficult since the concept of class combines objective and subjective factors, and it is also a political construct with various ideological agendas (as was demonstrated in recent British history with the importation from the US of the concept of the underclass, for example). When the notion of respectability, in other words moral standards, prevails over socioeconomic conditions to define classes, many pseudo-sociological representations come up to answer people's need for social groups or search for a collective identity, and the process of demonisation can readily take place. Off screen, hoodies have become very much like scarecrows because they embody just what the norm, the "squeezed middle", ${ }^{39}$ is afraid of becoming - sooner or later. That is why "we are 'othering' the poor" (Cadwalladr 2011) in a desperate attempt to make them remote from, or alien to, our comfortable world - a stance that was taken by genre films in its literal meaning. Whatever the label used to refer to this section of the population throughout the ages (dangerous classes, rough working class, underclass or more recently chavs and hoodies), the demonisation of the excluded, and especially of young working-class males, has followed a cyclical evolution (Welshman 2013: 2, 231, 234) sometimes mirrored in a twisted way by genre film cycles such as hoodie horror. The enemy image created around the figure of the hoodie is thus one of the latest cultural expressions of rising social inequalities in the UK. ${ }^{40}$

\section{BIBLIOGRAPHY}

Adetunji, Jo. "Iain Duncan Smith tells unemployed they should get on the bus to find work." The Guardian, 22 October 2010. http://www.guardian.co.uk/politics/2010/oct/22/iain-duncan-smithunemployed-get-on-the-bus 
Anonymous. "Under that hoodie is a child like yours." The Daily Mail, 15 May 2005. https:// www.dailymail.co.uk/columnists/article-348738/Under-hoodie-child-like-yours.html

Bawden, Fiona. "Hoodies or Altar Boys: What is Media Stereotyping Doing to our British Boys?" Women in Journalism, 10 March 2009. http://womeninjournalism.co.uk/hoodies-or-altar-boys

Benstead, Charlotte. "South London estate residents hit back over negative Channel 4 images." The Guardian, 23 January 2014. https://www.theguardian.com/housing-network/2014/jan/23/ south-london-aylesbury-estate-channel-4-campaign-ident

Blake, Linnie. The Wounds of Nations. Manchester: Manchester UP, 2012.

Bossuet, Jacques Bénigne. “Histoire des variations des églises protestantes”. Cuuvres complètes de Bossuet vol XIV. Paris: Louis Vivès, 1863.

Braddock, Kevin. “The Power of the Hoodie.” The Guardian, 9 August 2011. https:// www.theguardian.com/uk/2011/aug/09/power-of-the-hoodie

Brooke, Michael. “Teen Terrors on Film.” Screenonline, 2014. http://www.screenonline.org.uk/ film/id/1360926/index.html

Brooks, Libby. "Forget Zombie Dawn. Now it's Day of the Feral Youth." The Guardian, 18 September 2008. http://www.theguardian.com/commentisfree/2008/sep/18/horror.tonyblair Brunsdon, Charlotte. London in Cinema: The Cinematic City Since 1945. London: British Film Institute, 2007.

Cadwalladr, Carole. "Vajazzled! How chavs have replaced working class people on Britain's TV." The Guardian, 5 June 2011. https://www.theguardian.com/tv-and-radio/2011/jun/05/how-chavsreplaced-working-class

Cameron, David. “Cameron 'hoodie' speech in full.” BBC, 10 July 2006. http://news.bbc.co.uk/2/ hi/5166498.stm

Cameron, David. "PM's speech on the fightback after the riots." Gov.uk, 15 August 2011. https:// www.gov.uk/government/speeches/pms-speech-on-the-fightback-after-the-riots

Carroll, Noël. The Philosophy of Horror or Paradoxes of the Heart. London: Routledge, 1990.

Clarke, Donald. "Hoodie horror that hits home." The Irish Times, 22 June 2013. http:// www.irishtimes.com/culture/film/hoodie-horror-that-hits-home-1.1439724?page=3

Clover, Carol. "Her Body, Himself: Gender in the Slasher Film." Representations, Special Issue: Misogyny, Misandry, and Misanthropy 20 (1987): 187-228. DOI: 10.2307/2928507

DeFore, John. “Citadel: Film Review.” The Hollywood Reporter, 11 October 2012. http:// www.hollywoodreporter.com/review/citadel-film-review-378331

Featherstone, Mark. “'Hoodie Horror': The Capitalist Other in Postmodern Society.” Review of Education, Pedagogy, and Cultural Studies 35.3 (2013): 178-196. DOI: 10.1080/10714413.2013.799362

Fleming, Adam. "David Cameron and hug-a-hoodie phrase history." BBC, 6 June 2011. https:// www.bbc.com/news/av/uk-politics-13669826/david-cameron-and-hug-a-hoodie-phrase-history Graham, Jane. “Hoodies Strike Fear in British Cinema.” The Guardian, 5 November 2009. http:// www.theguardian.com/film/2009/nov/05/british-hoodie-films

Hasted, Nick. "Whatever happened to the working-class heroes of British film?" The Independent, 12 April 2018. https://www.independent.co.uk/arts-entertainment/films/features/british-filmworkingclass-hero-kitchen-sink-dramas-bfi-daniel-mays-david-morrissey-a8300876.html 
Hatfull, Jonathan. “Community DVD review." SciFiNow, 28 March 2013. http:// www.scifinow.co.uk/reviews/community-film-review

Helm, Toby and Anushka Asthana. "Unemployed told: do four weeks of unpaid work or lose your benefits.” The Observer, 7 November 2010. http://www.guardian.co.uk/politics/2010/nov/07/ unemployed-unpaid-work-lose-benefits

Hess, Alex. "Eden Lake: the film that frightened me most." The Guardian, 29 October 2014. https:// www.theguardian.com/film/2014/oct/29/eden-lake-the-film-that-frightened-me-most

Hutchings, Peter. "Uncanny Landscapes in British Film and Television." Visual Culture in Britain (5:2), 2004: 27-40.

Hutchings, Peter. "Horror London." Journal of British Cinema and Television 6:2 (2009): 190-206. DOI: 10.3366/E1743452109000879

Jones, Owen. Chavs: The Demonization of the Working Class. London: Verso, 2011.

Jones, Owen. "Benefits Street: A healthy media would stand up to the powerful and wealthy. Ours target the poor and voiceless." The Independent, 8 January 2014. https://www.independent.co.uk/ voices/comment/benefits-street-a-healthy-media-would-stand-up-to-the-powerful-and-wealthyours-targets-the-poor-and-9046773.html

Keesey, Douglas. Twenty First Century Horror Films. Harpenden: Kamera Books, 2017.

Leigh, Danny. "British cinema's exclusion of the young, skint and state educated is a national shame." The Guardian, 8 September 2018. https://www.theguardian.com/film/2018/sep/08/noroom-at-the-top-where-are-cinemas-few-working-class-stories-

Littlejohn, Richard. "The Politics of Envy was Bound to End Up in Flames." The Daily Mail, 12 August 2011. http://www.dailymail.co.uk/debate/article-2025021/UK-riots-2011-The-politicsenvy-bound-end-flames.html

Lönroth, Linn. "Hoodie Horror: The New Monster in Contemporary British Horror Film." Tidsskrift for Medier, Erkendelse Og Formidling 2.1 (2014): 4-20. https://tidsskrift.dk/mef-journal/ article/view/28650

McGarvey, Darren. Poverty Safari: Understanding the Anger of Britain's Underclass. Edinburgh: Picador, 2017.

McLean, Gareth. "In the Hood." The Guardian, 13 May 2005. http://www.theguardian.com/ politics/2005/may/13/fashion.fashionandstyle

McNulty, Ro. “'Because You Fear Them': On Citadel, class and 'hoodie' horror.” Empty Oaks, 9 February 2016. http://emptyoaks.com/2016/02/09/because-you-fear-them-on-citadel-class-andhoodie-horror/

Marin-Lamellet, Anne-Lise. "Le péril jeune : la représentation des jeunes des cités dans le cinéma britannique (1995-2012).” CinémAction (161) “Et les jeunes...”, Éditions Charles Corlet, 2016: 35-43. Marin-Lamellet, Anne-Lise. "De la confluence des genres comme art de la contrebande idéologique : Attack the Block (Joe Cornish, 2011).” SAES Conference paper, 2016.

Monbiot, George. "Britain's press are fighting a class war, defending the elite they belong to." The Guardian, 12 December 2011. http://www.guardian.co.uk/commentisfree/2011/dec/12/britainpress-fighting-class-war 
Murray, James, Dave Roberts and Matt Drake. "Should hooded youths be banned from our streets and shops?” The Daily Express, 30 March 2008. https://www.express.co.uk/comment/ haveyoursay/39640/Should-hooded-youths-be-banned-from-our-streets-and-shops Newman, Kim. Nightmare Movies: Horror on Screen Since the 1960s. London: Bloomsbury Publishing, 2011.

Plunkett, John. "Benefits Street adds nearly 1 million viewers for second episode." The Guardian, 14 January 2014. https://www.theguardian.com/media/2014/jan/14/benefits-street-viewerschannel-4

Simpson, M.J. Urban Terrors: New British Horror Cinema 1997-2008. London: Hemlock Books Limited, 2012.

Taylor, Drew. "Citadel is a Sometimes Scary, Sometimes Silly Entry in the Hoodie Horror SubGenre." IndieWire, 8 November 2012. https://www.indiewire.com/2012/11/review-citadel-is-asometimes-scary-sometimes-silly-entry-in-the-hoodie-horror-sub-genre-104291/\#!

Tilly, Chris. “Eden Lake UK Review.” IGN, 12 September 2008. https://www.ign.com/articles/ 2008/09/12/eden-lake-uk-review

Tookey, Chris. "Eden Lake: A Great Movie (if you can stomach it).” The Daily Mail, 11 September 2008. http://www.dailymail.co.uk/tv showbiz/article-1054787/Eden-Lake-A-great-moviestomach-it.html

Tyler, Imogen. Revolting Subjects: Social Abjection and Resistance in Neoliberal Britain. London: Zed Books, 2013.

Walker, Johnny. Contemporary British Horror Cinema: Industry, Genre and Society. Edinburgh: Edinburgh UP, 2016.

Ware, John. "Yes Family Breakdown is behind Broken Britain." The Daily Mail, 11 July 2009. https://www.dailymail.co.uk/debate/article-1198962/Yes-family-breakdown-IS-broken-BritainTop-judge-says-national-tragedy-attacks-BBC-suppressing-debate.html

Welshman, John. Underclass: A History of the Excluded since 1880. London: Bloomsbury, 2013.

Wintour, Patrick. "George Osborne to cut $£ 4 b n$ more from benefits." The Guardian, 9 September 2010. http://www.guardian.co.uk/politics/2010/sep/09/george-osborne-cut-4bn-benefitswelfare

\section{Filmography}

1 Day. Woolcock, Penny dir. Momentum Pictures DVD. 2009. $98 \mathrm{mn}$.

A Clockwork Orange. Kubrick, Stanley dir. Warner Bros DVD. 1971. $131 \mathrm{mn}$.

Antisocial Behaviour. Pike, Vinson dir. S'more Entertainment DVD. 2007. 90 mn.

Attack the Block. Cornish, Joe dir. Optimum Home Entertainment/Studiocanal DVD. 2011. 88 mn. Brighton Rock. Boulting, John dir. Warner Bros DVD. 1947. 89 mn.

Cherry Tree Lane. Williams, Paul Andrew dir. Metrodome DVD. 2010. 74 mn.

Citadel. Foy, Ciaran dir. Metrodome DVD. 2012. 84 mn.

Comedown. Huda, Menhaj dir. Studiocanal. 2011. 90 mn.

Community. Ford, Jason dir. Matchbox Films. 2012. 78 mn. 
Cosh Boy. Gilbert, Lewis dir. BFI DVD. 1953. $75 \mathrm{mn}$.

Don't Look Now. Roeg, Nicolas dir. Studiocanal DVD. 1973. 110 mn.

Eden Lake. Watkins, James dir. Optimum Home Entertainment DVD. 2008. 87 mn.

F. Roberts, Johannes dir. Optimum Home Entertainment DVD. 2010. 76 mn.

Harry Brown. Barber, Daniel dir. Lionsgate DVD. 2009. $99 \mathrm{mn}$.

Heartless. Ridley, Philip dir. Lionsgate DVD. 2009. $109 \mathrm{mn}$.

Psycho. Hitchcock, Alfred dir. Universal Pictures UK DVD. 1960. 109 mn.

The Boys. Furie, Sidney J. dir. Renown Pictures DVD. 1962. 118 mn.

The Disappeared. Kevorkian, Johnny dir. Soda Pictures DVD. 2012. 93 mn.

The Guvnors. Turner, Gabe dir. Metrodome DVD. 2014. 91 mn.

The Village of the Damned. Rilla, Wolf dir. Warner Home Video DVD. 1960. 77 mn.

Tower Block. Thompson, Ronnie \& Nunn, James dir. Lionsgate DVD. 2011. 87 mn.

Violent Playground. Dearden, Basil dir. ITV Studios DVD. 1958. $102 \mathrm{mn}$.

\section{NOTES}

1. The hoodie has become the "signifier of generic urban menace" (DeFore 2012), "the signifier par excellence of terror and fear in the diegetic, and the extra-filmic, world" (Walker 2016: 94), and "a signifier of disgruntled, malevolent youth, scowling and indolent [...] the uniform of the troublemaker: its wearer may as well be emblazoned with a scarlet letter" (McLean 2005). Even the then Leader of the Opposition David Cameron (2006) spoke of the hoodie as "the uniform of a rebel army of young gangsters".

2. Philip Ridley, director of Heartless, concurs in the DVD commentary: "there is something demonic in a hood".

3. Gangs of hoodies are overwhelmingly, if not exclusively, male. When girls are featured, they are ancillary and totally dominated. For more, see Anne-Lise Marin-Lamellet (2016a: 36-7).

4. The credits of Community refer to "pack leader", "pack members" and "hoodie on bike" for some of its cast.

5. Jane Graham (2009) even sees a vampiric or zombie quality in hoodies. Community does allude to blood feeding monsters.

6. Aylesbury was also the location chosen by Tony Blair for his first speech as Prime Minister to launch his policy about "the forgotten people" (Welshman 2013: 192).

7. "It seemed a given that council flats rather than castles would become the real estate of choice for the new Gothic. [...] The seediness and deprivation are exaggerated almost cartoonishly, the imagined estates leaving realism behind and transforming into the 'ghettoes' of middle-class nightmares: lawless no-go areas in which the protagonists are victimized simply for not belonging" (McNulty 2016). As such, these estates are coded as "not-home" and echo the house or tunnel trope noticed by Clover in slasher films (originating in Psycho) or, to a certain extent, the unfamiliar, hostile, vacant and dispossessed landscapes studied by Hutchings.

8. Directors and producers explain how difficult it often was for them to find a suitable location for the shoot; most of these estates having been gentrified in the run-up to the 2012 London Olympics (see the DVD bonus of Comedown at 12', for example). That led them to either work on estates awaiting demolition or constructing a set in a studio. What is overlooked is that the real 
situation may not be as bad as what the media seem to think. Channel 4 shot one of its idents on the Aylesbury estate and then reworked it with digital effects to make it much drabber and filthier (see on Youtube: https://youtu.be/ZFvq1QlDXTE), which led to the complaints of residents and an alternative video (see on Vimeo: https://vimeo.com/72499069) to show the reality of the place including its people (Benstead 2014).

9. The wish to combine "raw, authentic, gritty, kitchen sink" elements and genre film tropes has been variously acknowledged by directors/scriptwriters themselves: see, among many examples, Johnny Kevorkian or Daniel Barber in Graham (2009) and James Watkins in Simpson (2012: 266); and by critics: Simpson (2012: 267-9), Clarke (2013), Walker (2016: 87). More generally, the whole new wave of British horror films has been characterised by the resort to social realism (Simpson 2012: 13, 64)

10. The trailers of $F$. and Community respectively claim "based on real events" and "the horror is coming to your neighbourhood". DVD sleeves use the same strategy. Community reads "the horror is closer than you think".

11. John Welshman (2013: 4, 234) explains how the term underclass which is often associated with hoodies has been used as a potent symbol to express fears and anxieties throughout the decades although there has always been a lack of empirical evidence to support the concept. The expression "more research was needed" is like a running gag in the book $(67,76,121,144,147$, $161,173,175,178,179)$.

12. Several journalists pondered over that paradox when the Bluewater shopping centre decided to ban hoodies from its premises in 2005 and in the wake of the 2011 riots (McLean 2005; Anonymous 2005). Kevin Braddock (2011) notes: "not every kid in a hoodie [is] necessarily 'a hoodie'."

13. John Welshman (2013: 79-97, 185-228) shows that the concept of problem families was already discussed in the 1940s before being revived by the New Labour and Coalition governments.

14. Backwoods, despite its rural context, is very similar to hoodie horror since both subgenres are based on a Dantesque vision of lower classes, an underclass left to fend for itself in neglected/ abandoned areas, resulting in a sort of sociobiological degeneracy. Rural or suburban hoodies are also very close to the hillbillies of American backwoods films in that they are reluctant to cultural assimilation. The local community seen in Eden Lake or Community is perceived as all the more monstrous as these people are "tied firmly to a sense of place and an extended kinship structure, a distinct cultural milieu with its own sense of history, tradition and class. Being less an individual than a member of an entire social group that challenges the totalising claims for national identity" of Middle England (Blake 2012: 147). See also Ro McNulty (2016) who speaks about "redneck horror" as hoodie horror's "American cousin". That may be why the gang who hunts the couple (Eden Lake) is sometimes represented like Indians ambushing cowboys standing on the top of a hill.

15. Citadel was considered particularly shocking, even among horror specialists' circles, for its bleakness and "noxious overtones" (Taylor 2012; DeFore 2012).

16. David Cameron's Speech to the Centre for Social Justice is better known as the "hoodie speech". As then new Leader of the Opposition, Cameron wanted to rebrand his party which for years had been in the political doldrums. Willing to present a more modern, compassionate type of conservatism, he delivered an emotional speech on the importance of tackling the long-term causes of youth crime and various social justice issues rather than focusing on short-term crackdown solutions, which was unusual given Conservative rhetoric on law and order. The phrase "hug-a-hoodie" came from a Labour Party statement to criticise Cameron's going soft on crime (Fleming 2011).

17. For more examples, see Imogen Tyler (2013: 179-206).

18. Members of the latter talked about a "habit of worklessness" (Helm 2010). Iain Duncan-Smith, then Secretary of State for Work and Pensions, was said to be Norman Tebbit's clone as he 
encouraged the unemployed to get on the bus to look for work (Adetunji 2010). George Osborne, then Chancellor of the Exchequer, referred to unemployment as being "a lifestyle choice" (Wintour 2010). As for David Cameron (2011) who had operated a massive U-turn on his crime policy since his Opposition days, he referred to gang culture in the wake of the riots as "a major criminal disease that has infected streets and estates across our country."

19. Some critics are aware of those generic conventions (Graham 2009). Besides social dramas, films presenting hoodies sometimes use unexpected genres to try and rehabilitate them such as the musical 1 Day. It is to be noticed that even hoodie horror films feature "good" hoodies vs "bad" ones (The Disappeared, Heartless, Comedown, Citadel).

20. See, for example, Paul Andrews Williams in the DVD commentary of Cherry Tree Lane at 32' and Steven Kendall for Comedown at 1', 4'.

21. Incidentally, it may also say something about the state of the British film industry that has been regularly accused of being overwhelmingly dominated by middle-class professionals who have little insight into real working-class life (Leigh 2018, Hasted 2018).

22. Eden Lake shows the heroine's arc from a caring teacher to a child killer. The heroine shouts and has the same evil face as the psychotic gang leader. Contrariwise, a film like Community shows that, even in the heart of darkness, some hoodies' mothers are not as bad as their offspring.

23. This question is alluded to by Darren McGarvey (2017: 124-5) who explains how the dominant classes, owing to their cultural prominence, assume their interests, preferences and aspirations are universal. They are therefore prone to deem countercultural anything outside of their frame. 24. Off screen, this point was made by a columnist (Anonymous 2005): "OUR [emphasis in the original] communal spaces no longer feel communal because there is no sense of collective responsibility for what happens on them. [...] Instead of slapping Asbos [Anti-Social Behaviour Orders, obtained by local courts] on dispossessed kids and demonising every teenager in a hoodie, we need to look far deeper into what has undermined our communities." See also John Ware (2009).

25. "Despite the criticism it received, [Citadel]'s (very literal) demonization of young people is too obvious to be taken at face value. [...] This assertion, that the fear of their would-be victims is the youth's greatest strength, is something worth thinking about. [...] It serves as a message for the hoodie horror movement and British culture more generally: the hoodies are not out to get you, they are not interested in you, and if you're scared of them, it's your problem, not theirs" (McNulty 2016).

26. Darren McGarvey (2017: 38, 50-1, 76, 87-8, 91-2, 145) makes the same observation after repeatedly explaining the dangers created by the widening inequalities in the UK. He uses several images (ravine, gulf, chasm) to refer to that divide and argues that it has to be bridged through communication and better mutual awareness so that the inaccurate assumptions, misunderstanding and resentment between classes do not precipitate the country into tribalism.

27. For more details about this case of rural gentrification, see Johnny Walker (2016: 101) and Douglas Keesey (2017: 132-3).

28. "Horror film is uniquely situated to engage with the insecurities that underpin such conceptions of the nation; to expose the terrors underlying everyday national life and the ideological agendas that dictate existing formulations of 'national cinemas' themselves" (Blake 2012: 9). See also Libby Brooks (2008).

29. Off screen, the same point is made by Owen Jones (Cadwalladr 2011). "He cites the case of Shannon Matthews: the newspaper reporters sent to cover it likened the council estate in Dewsbury to Afghanistan. It was so far out of their sphere of experience, they literally had no point of reference to understand it; unlike the other missing child of the moment, the middleclass Madeleine McCann."

30. James Watkins confirms in the DVD bonus that all the characters in Eden Lake are ambivalent. 
31. Joe Cornish confirms in the DVD commentary of Attack the Block: "Horror is moral. Not gratuitous and indulgent". For more about the ideology of horror, see Noël Carroll (1990: 195-205).

32. This oft-mentioned reference is actually an apocryphal rephrasing and translation of the original sentence: “Mais Dieu se rit des prières qu'on lui fait pour détourner les malheurs publics, quand on ne s'oppose pas à ce qui se fait pour les attirer. Que dis-je? quand on l'approuve et qu'on y souscrit, quoique ce soit avec répugnance" (Bossuet 1863: 145).

33. For a list of recent TV programmes that have incited to class hatred by reinforcing assumptions, see Owen Jones (2014) and Carole Cadwalladr (2011) who cites "a YouGov poll from 2006 which asked professionals working in television whether Vicky Pollard was an accurate representation of the white working class. A mind-boggling $70 \%$ said yes". The difference may be due to the fact that television tends to focus on chavs as a source of mockery while hoodie horror, as the name shows, generates fear (Walker 2016: 88).

34. Interestingly, the fear generated by hoodies is acknowledged by journalists from opposite sides of the political spectrum. But the difference is that while Chris Tookey (2008) does not seem to have qualms about it, Libby Brooks (2008) feels bad about admitting that fact. The nature of their horror may thus not be exactly the same. In one case, he is disgusted at the hoodies; in the second, she is disgusted at the idea of being terrorised by them. See also Alex Hess (2014): "Maybe its real brilliance lies in its effect on Guardian-reading liberals like me and you: the instinctive fear provoked by its tracksuited executioners showing how the sort of reactionary conservatism that you define yourself against is actually within us all."

35. Some organisations have also pointed out that distortion by analysing the kind of words regularly associated with young Britons over 8,000 press articles. The result speaks for itself: “ yobs, thugs, sick, feral, hoodie, louts, heartless, evil, frightening, scum, monsters, inhuman, threatening" (Bawden 2009). The ultimate irony is that teen boys are influenced by the bad press they get. "It seems that the endless diet of media reports about yobs and feral youths is making them fearful of other teens" (Bawden 2009).

36. The film was released in 2011, which enables it to play with the conventions already established in previous films. Film cycles often generate their own parodies at the end of their genre exploitation. For a detailed analysis of the film, see Anne-Lise Marin-Lamellet (2016b).

37. "Great horror movies comment on the world. Great comedies do likewise. Both genres exaggerate - only slightly - to explore the human condition and, when they are of a time and a place, to hold a mirror up to that world." That is what a film like Eden Lake does, taking "the full munch of Daily Mail terrors and [turning up] the volume, hard" (Simpson 2012: 113, 269). See also Johnny Walker (2016: 97) about how hoodie horror films make tabloid generalisations apparent and Douglas Keesey (2017: 133) although he admits that the critique expressed sotto voce in these films might not register with everyone.

38. Besides the media and politicians, the problem may come from people themselves since the middle class is the class that refuses to name itself as Darren McGarvey $(2017: 31,123)$ implies, although class is still a major dividing line to define one's culture and identity.

39. Libby Brooks (2008) makes a connection between that section of society and the fear out of which hoodie horror is born: "But who are the 'we' and the 'us' in this debate? [...] An essential part of being middle class in an unequally privileged society is anxiety. While the extreme disconnect between the Bollinger-spraying banker and the estate single mother is easier to compute, it's the precarious middle class, most often just a generation away from being poor, who have so much more to lose." See also John Welshman (2013: 189).

40. As Kevin Braddock (2011) muses, the real meaning of the hoodie might be the lack of opportunities of its wearer: "kids in hiding, afraid of being seen, and at the same time embodying in their everyday uniform the furtive tunnel-vision that seems to define their bleak, introspective vision of the world outlook." 


\section{ABSTRACTS}

The late 2000s and early 2010s saw the rise of a new subgenre in British horror cinema now often referred to as hoodie horror. Government and media campaigns against antisocial behaviour or Broken Britain under Blair and Cameron's premierships undoubtedly helped revive the stereotype of a rebellious and dangerous youth, also a great cinematic trope, which culminated with the summer riots of 2011. The enemy image of the hoodie thus gelled on and off screen around the powerful symbol of that garment. Because of the possibilities offered by genre films, the often claimed "feral" nature of these creatures is sometimes taken in a literal sense and young people from sink estates are presented as amoral and bloodthirsty monsters causing the general collapse of society. These gangs of predators appear to be fascinated by their own evil image that they proudly advertise through the use of social media. Hoodies are thus othered, but they also ironically reclaim that enemy image. Hoodie horror has sometimes been criticised because of its perceived conservative or even reactionary and/or racist overtones. Allegedly feeding on and fuelling moral panic, it may perpetuate clichés about a so-called new underclass, thereby further blurring the thin boundary between reality and fantasy for spectators. As a byproduct of neoliberalism, it is deemed to depoliticise or deny the wider social context in order to better essentialise evil through the construction of a new folk devil. To a certain extent, this cycle of films does reinforce the horrific character of poor British youths, presenting them not only as culturally but also biologically different. However, this interpretation has to be mitigated. Many of these films play with the conventions of a subgenre inspired by several American models in order to somehow subvert and question the enemy image given to hoodies as they implicitly point to the society that generates, to better demonise, these new evil hordes. By putting the media and their effects into perspective, by looking at the other side i.e. the victims of hoodies (Middle England, "us", spectators) and questioning their own values and attitudes, these films finally advocate sotto voce a discourse that is quite pessimistic but not as cynical and hostile towards these youths as expected. The worst enemy of the nation may be the excommunicators.

La fin des années 2000 et le début des années 2010 ont été marqués au Royaume-Uni par la vague d'un sous-genre du cinéma d'horreur, le hoodie horror. Les campagnes médiatiques contre les incivilités, l'obsession des gouvernements Blair et Cameron envers les comportements antisociaux ont sans doute ravivé le stéréotype d'une jeunesse révoltée et dangereuse, grand classique du cinéma en général et du cinéma britannique en particulier, qui a culminé avec les émeutes de l'été 2011. L'image d'un nouvel ennemi de la nation s'est donc forgée à la ville et à l'écran autour de la symbolique dégagée par ce vêtement qu'est le sweat à capuche (hoodie). Le prisme du genre permet au cinéma de littéraliser certains éditoriaux des tabloïds en montrant des jeunes de banlieue comme des monstres amoraux et sanguinaires. Ces groupes de prédateurs semblent de plus en plus fascinés par leur propre image maléfique qu'ils diffusent sur les réseaux sociaux. Les hoodies revendiquent donc leur image d'ennemi. Ce sous-genre souffre souvent d'une mauvaise réputation car il demeure perçu comme conservateur, voire réactionnaire et raciste : il est accusé de participer à la phobie ambiante en perpétuant les clichés médiatiques à propos d'une supposée nouvelle underclass et, à ce titre, de brouiller la frontière entre réalité et fantasme. Pur produit du néolibéralisme, il chercherait comme lui à dépolitiser ou nier les problèmes sociaux pour mieux essentialiser le mal à travers la figure d'un jeune qui sert de boucémissaire à une société aliénée par ses dirigeants et ses médias. Dans une certaine mesure, ces films renforcent effectivement le caractère terrifiant de ces jeunes en les présentant comme différents, non seulement culturellement mais aussi biologiquement. Cependant, cette vision doit être nuancée. Nombre de ces films jouent sur les codes d'un sous-genre inspiré de plusieurs 
modèles américains pour subvertir quelque peu cette image de l'ennemi et dénoncer implicitement la société qui produit ces nouvelles hordes pour mieux les diaboliser. En remettant en question le rôle des médias et de leurs effets, en s'intéressant à l'autre partie, en d'autres termes aux victimes des hoodies (les classes moyennes anglaises, la majorité silencieuse, les spectateurs supposés de ces films) et en interrogeant leurs propres valeurs et attitude, ces films font passer sotto voce un discours pour le moins pessimiste mais pas aussi cynique et hostile envers ces jeunes qu'on pourrait le croire de prime abord. Les pires ennemis de la nation pourraient in fine être les excommunicateurs.

\section{INDEX}

Keywords: hoodie, underclass, antisocial, class, horror, British cinema, enemy image, cinema, United Kingdom

Mots-clés: hoodie, underclass, antisocial, classe, horreur, cinéma britannique, image ennemie, cinéma, Royaume-Uni

\section{AUTHOR}

\section{ANNE-LISE MARIN-LAMELLET}

Anne-Lise Marin-Lamellet is a senior lecturer in English at the University of Saint-Etienne, France. In the field of British studies, she works on contemporary British cinema focusing on class, race and gender issues. She wrote a PhD entitled "The working class hero through British cinema since 1956" and published various articles about Mike Leigh, Ken Loach, Tony Richardson, Chris Morris, working-class memory in the British New Wave, the North/South border, pastoral, the margin/periphery dialectic in British films, the representation of strikes, youths, single mothers, etc. Contact: anne.lise.marin.lamellet[at]univ-st-etienne.fr 